\title{
Development of Learning Modules Based on a Realistic Mathematical Approach with Autograph Software to Improve Creative Mathematical Thinking Ability Students of SMP Negeri 1 B langkejeren
}

\author{
Rike Ahmadi', Edi Syahputra ${ }^{2}$, Bornok Sinaga ${ }^{3}$ \\ ${ }^{1,2,3}$ Universitas Negeri Medan, Indonesia \\ rikeahmadi@gmail.com edisyahputra01.es@gmail.combsinaga@unimed.ac.id
}

\begin{abstract}
This study aims to analyze the practicality of the learning modules developed based on the Realistic Mathematical Approach with autograph software, to analyze the effectiveness of the learning modules developed based on the Realistic Mathematical Approach assisted by autograph software, and to describe the improvement of students' mathematical creative thinking abilities through learning modules developed based on the Mathematical Approach. Realistic assisted autograph software. The data were obtained through the learning module validity sheet consisting of the lesson plan validation sheet and the mathematical creative ab ility test validation sheet, student response questionnaires and teacher interview guidelines for the learning module and the learning module effectiveness instrument seen from the students' mathematical creative test results. Module development in this study uses the Thiagarajan, Semmel and Semmel development models, namely the 4-D model (define, design, develop, disseminate). The results of the research were students and teachers stated that the developed device was easy to use, the students' critical thinking ability obtained classical completeness with a percentage of $87.5 \%$, the level of student activity met the ideal time tolerance criteria set, student responses to the components of learning devices and learning activities is positive. The increase in creative thinking skills in the first try was 77.9, an increase in the second try to 81.64.
\end{abstract}

Keywords

module development; realistic mathematical approach;

mathematical creative thinking ability;

autograph

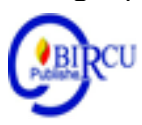

\section{Introduction}

Regulation of the Minister of Education and Culture number 21 of 2016 concerning content standards for primary and secondary education for mathematics, namely showing attitude, logic, criticism, analytical, creative, careful and thorough, responsible, responsive, and not easy to give up in solving problems. From the Minister of Education and Culture, it can be seen that mathematics can train students' logic, argumentation and creativity. Besides that, it can also foster student responsibility, diligence and responsiveness. So it can be concluded that mathematics is an important subject for students to master. 
Improving the quality of mathematics learning in Indonesia, according to the demands of the 2013 curriculum, requires various efforts. Educational design that provides opportunities for students to develop their potential in a fun learning atmosphere and in accordance with their abilities. Along with the development of the internet, the learning strategy has shifted and various information and communication technology-based learning strategies have emerged from the e-learning model, smart classroom technology, virtual classroom, belded learning, etc. (Fitri \& Zahari, 2019).

Conditions in the field are inversely related to the importance of mathematics. Most students think of mathematics as a difficult and scary subject. So that students tend to dislike and avoid learning mathematics. This can be seen from the results of UNBK SMP 2019 from the set competency standards of 55 points, mathematics only obtained 46 points. This result is not much different from 2018 which also experienced a decline.

In addition to the results of UNBK SMP, researchers also conducted interviews with mathematics teachers at SMP Negeri 1 Blangkejeren on August 20, 2019 regarding the obstacles faced by teachers in learning mathematics, He stated that students often had difficulty working on questions whose solutions were different from the example questions. Students find it difficult to answer if there is a change in the questions from the questions students usually do. There are even students who cannot answer at all if the answers to the questions asked must be different from the existing sample answers. From the problems faced by the teacher, it can be concluded that the ability needed to be able to answer with unique, new and varied answers is the ability to think creatively.

McGregor (Mahmudi, 2009) states that creative thinking is a type of thinking that directs the acquisition of new insights, new approaches, new perspectives, or new ways of understanding something. Both of these opinions indicate that higher-order thinking skills will occur when a student can relate new information to the information he already has in his memory and connect or rearrange and develop information to achieve a goal or find a solution to a difficult situation / problem solved.

To increase the creativity abilities of students, according to Wankat and Oreovoc in (Wena, 2008) it can be done by (1) encouraging students to be creative (tell student to be creative), (2) teaching students several methods to be creative (teach student some creativity methods), and (3) accept the creative ideas produced by students (accept the result of creative exercise).

According to Martin (2009) the ability to think creatively is "the ability to generate new ideas or ways of producing a product". In general, creative thinking is triggered by challenging problems. Martin also suggests three aspects of creative thinking abilities, namely productivity, originality or originality, and flexibility or flexibility. Productivity is related to the number of works produced. Originality relates to a work that is different from similar works around it. Flexibility refers to the willingness to modify beliefs based on new information. Someone who does not think flexibly does not easily change their ideas or views even though he knows that there are contradictions between the ideas he has and the new ideas.

Based on the descriptions that have been stated above, the ability to think creatively is the ability to think at a higher level which is obtained through the process of trying, investigating, discovering, and applying various new ideas. Indicators of creative thinking in this study are limited to: (1) the ability to generate a number of new ideas, (2) the ability to generate various ideas, (3) the ability to generate unique ideas.

Through good mathematics education, students can indeed obtain various kinds of provisions in facing challenges in the global era. In the 2013 curriculum itself, the use of 
technology in learning became something that was highly recommended. The learning process in the 2013 curriculum requires students to participate actively and provide sufficient space for students' creativity, interests, and talents (Fitri, Syahputra, \& Syahputra, 2019).

Mathematics learning tools as a means of achieving the goals of the educational curriculum are an important part of the learning process, as well as guidelines for teachers in carrying out the learning process in the classroom. Mathematics as a basic science is one of the subjects that play an important role in every level of education as a means of logical, critical, analytical, rational and systematic thinking (Rambe, 2020). Irhamna (2020) stated that mathematics is a universal science. Mathematics is also seen as the queen of science. This aims to determine the extent to which the learning material has been presented, what indicators are to be achieved, and how the teacher will follow up. In addition, the learning device also aims to help students follow the mathematics learning process. This is in line with PP. 19 of 2005 on SNP states, "The curriculum is a set of plans and arrangements regarding the objectives, content, and learning materials as well as the methods used as guidelines for implementing learning activities to achieve certain educational goals".

One of the learning approaches that teachers can use in the learning process is a realistic approach. In mathematics, the realistic approach is stated as a realistic mathematics approach, where in the learning process students are given the opportunity to understand and discover mathematical concepts themselves, then guided by the teacher to correct concepts that are misunderstood by students. This is in accordance with the statement of Dickinson \& Hough (2012) that teachers who use realistic mathematics state that realistic mathematics is able to increase students' understanding to understand and apply mathematics.

Learning with a realistic mathematics approach is a learning approach that must start with something real (real), so that students can be involved in the learning process in a meaningful way. It can be concluded from Dickinson \& Hough (2012) that the advantages of a realistic mathematics approach include:

1. Teaching with PMR resulted in a change in the way the teachers saw learning and teaching mathematics. This is indicated by the beginning of teaching with PMR, where teachers previously experienced anxiety which they believed to be their challenges.

2. Students will feel a significant change in the way the teacher teaches and can be sure that it will have a very significant impact on students and this impact can be seen during learning.

3. Data obtained from students in daily learning, both the value obtained from the test results and learning will show a very significant positive impact. This will be more visible at the end of the lesson, when the results of small group work (student answers) are collected.

Furthermore, looking at the development of the millennial world, researchers caught a signal that the younger generation is currently very interested in technology. This is proven by the rapid development of technology in Indonesia and the consumers are mostly young people. Android applications are so loved that almost all junior high school students already have their own android. This has attracted researchers to use technology in the design of the modules to be developed.

The many mathematical software available, researchers chose autograph software as the technology to be used in the developed module. The reason for choosing autograph software is because autograph software has never been implemented at the research site and autograph software is software that does not require an internet connection to use, thus saving application costs. Furthermore, the autograph software is also compatible with the material being taught, namely straight line equations. 
Starting from the weak mathematical creative thinking ability, the importance of this is based on its very importance in learning mathematics, as well as the results of field observations which show that this weakness cannot be separated from the learning tools used in the field, so to solve the problems found the researchers provide solutions in the form of developing based learning modules. a particular model / approach that focuses on improving students' mathematical creative thinking skills. For this reason, the research that will be carried out is the Development of Learning Modules based on a Realistic Mathematical Approach with the help of Autograph Software to Improve the Mathematical Thinking Ability of Students of SMP Negeri 1 Blangkejeren.

\section{Research Methods}

The subjects in this study were students of Class VIII SMP Negeri 1 Blangkejeren and as objects in this study were learning modules based on the Realistic Mathematical Approach assisted by autograph software.

Learning modules that have met the validity criteria are tried out in classroom learning. Field trials were carried out to obtain direct input on the learning modules that had been compiled in the framework of revision of Draft II. The learning module will be tested in pilot schools to see the effectiveness of the learning modules that have been designed and see the increase in students' mathematical creative abilities. The trial results were used as the basis for refining Draft-II to Draft III (final draft).

The trial design of this study used the One Group Pretest - Posttest Design (Tuckman, 1978). The first step is to take measurements as a pretest, then subject to treatment within a certain period of time, then a posttest is carried out. The research design of the pre-test and post-test design is with the following pattern:

\begin{tabular}{|ll|}
\hline$O_{1}$ & $\times$ \\
\hline
\end{tabular}

Information:

$\mathrm{O}_{1}$ : The pretest is conducted to determine the level of students' mathematical creative abilities before being given treatment.

$\mathrm{X}$ : Treatment through learning using a realistic mathematics approach based learning module assisted by

autograph software that has been developed.

$\mathrm{O}_{2}$ : The final test (posttest) is conducted to determine the level of students' mathematical creative abilities.

The purpose of implementing the learning module trial for know the clarity of the readability of the learning module by implementing trials. In the trial, it was recorded all the activities that appeared, whether the students reached the goal mastery level, whether the teacher had carried out the learning according to the plan. Meanwhile, the student's creative mathematical ability test is a test that aims to determine whether the developed test can measure the mathematical creative ability. One of several learning approaches that is thought to help foster students' understanding of mathematical concepts is the Realistic Mathematics Approach (Adliani, 2020).

Research instruments and data collection techniques were prepared to measure the validity, practicality and effectiveness of developing learning modules with a realistic mathematics approach. To measure the validity of the instrument used in this study, the learning module validity sheet consisted of the lesson plan validation sheet and the 
mathematical creative ability test validation sheet. To measure the practicality of the instruments used in this study were student response questionnaires and teacher interview guidelines for the learning module and the instrument for the effectiveness of the learning module seen from the results of students' mathematical creative tests.

The development of modules in this study uses the Thiagarajan, Semmel and Semmel (1974) development model, namely the modified 4-D model (define, design, develop, disseminate). In addition to the learning module, a Learning Implementation Plan (RPP) based on the Realistic Mathematical Approach was also developed. In addition, research instruments were also developed in the form of tests of mathematical creative thinking abilities, student response sheets, and validation sheets.

\section{Discussion}

Student responses to the learning modules developed are positive, students find it easy to use them. In fact, many students study hard after using the learning module, and the display and pictures in the book encourage students to pay attention to what they are learning. In addition, students are also very interested in working on the questions because the module is equipped with instructions. This shows that students think that the learning module used is practical. But there is a statement "This learning module makes me more active in studying" which is still in the sufficient category. This will be revised material for trial II.

The teacher's response to the learning module developed was very positive, the teacher found it easy to use it. The teacher also feels interested and helped by the instructions in its implementation. This shows that the teacher considers the learning module used is practical.

From the results of the description above related to the implementation of the learning module, the overall indicators of practicality in this study meet the following criteria: (1) students say that the learning module used is easy to use; and (2) the subject teacher said that the learning module used was easy to use; Based on the achievement of the practicality indicators of the learning module, the learning module developed can be said to be practical.

In this study, the level of mastery of students in terms of mathematical creative thinking skills using tests of mathematical creative thinking skills that have been developed. The description of the results of students' mathematical creative thinking abilities in the first trial is shown in Table 1.The following:

Table 1. Descriptions of Students' Mathematical Creative Thinking Ability

Results in Trial I

\begin{tabular}{|c|c|c|}
\hline Information & Pretest & Posttest \\
\hline $\begin{array}{c}\text { The highest } \\
\text { score }\end{array}$ & 87,5 & 93,75 \\
\hline Lowest Value & 41,67 & 58,33 \\
\hline Average & 63,54 & 77,99 \\
\hline
\end{tabular}

The percentage of classical completeness criteria for students' mathematical creative thinking abilities in the first trial is presented in Figure 1. 


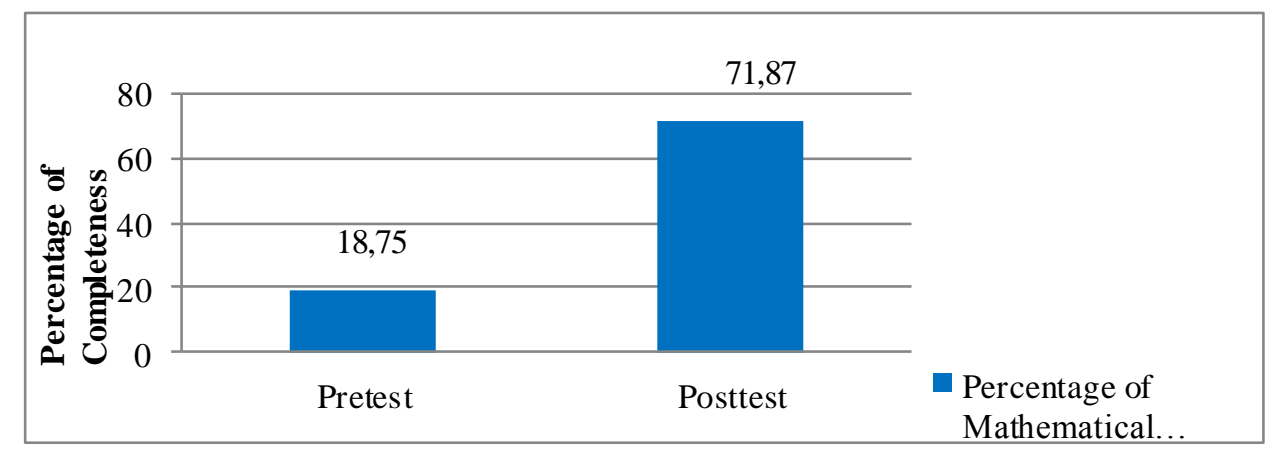

Figure 1. Percentage of Classical Completeness of Creative Thinking Ability Mathematical Students in Trial I

Based on the data in Table 1 and Figure 1, it can be seen that the classical completeness of the results of students' mathematical creative thinking abilities in the pretest first trial was $18.75 \%$ while in the posttest trial I was $71.87 \%$. In accordance with the completeness criteria of classical student learning outcomes, namely at least $85 \%$ of students who took the mathematical creative thinking ability test were able to achieve a score of $\geq 75$.Thus, the posttest results of students' mathematical creative thinking abilities did not fulfill classical completeness because they only obtained a percentage of 71 completeness. $87 \%$. So it can be concluded that in Trial I, the application of a learning module based on a realistic mathematical approach with the help of the Autograph developed did not meet the classical completeness criteria.

The average percentage of student activity in listening to / paying attention to the teacher / friend's explanation at each meeting that was held had met the effectiveness limit. The percentage of student activity at each meeting was $23.1 \%, 25.4 \%, 21.1 \%$ and $21.6 \%$. This indicates that students in starting learning have listened to / paid attention to the teacher's explanation because the learning they are doing has never been done before and they are more active in learning.

The average student reads the contextual problem in the student module at each meeting that had met the effectiveness limitation criteria. The percentage of student activity at each meeting was $15.7 \%, 14.4 \%, 15.7 \%$ and $14.4 \%$. This indicates that students have discussed a lot of contextual problems in student modules and they are more independent and active both individually and in groups. The average student in solving problems / finding ways and answers to problems has met the effectiveness limitation criteria. The percentage of student activity at each meeting was $24.6 \%, 21.1 \%, 24.6 \%$, and $25.2 \%$. This indicates that it has met the effectiveness criteria.

Based on the results of the student response questionnaire analysis, it can be seen that the average results of the percentage of students' positive responses to each aspect of student responses are as follows: (1) students who expressed pleasure in the learning module components were $76.25 \%$; (2) students stated that the components of the learning module and learning activities were still new as much as 80\%; (3) students who expressed interest in learning mathematics in other materials such as learning conducted were $87.5 \%$; (4) students who stated that the language in the module, LAS and tests was clear was 87.5\%; (5) students who expressed interest in the performance of the module and LAS were 93.75\%; and (6) students who stated that learning based on a realistic mathematics approach assisted by an autograph was interesting, made fun, useful and helpful, and motivated in learning mathematics as much as $88.75 \%$. The average percentage of total student positive responses in Trial I was $83.12 \%$. If the results of this analysis are referred 
to the criteria, it can be concluded that students' responses to learning components and activities are very positive. This is because more than $80 \%$ of students responded positively to the components of the learning module being developed.

In the first trial, the effectiveness of the developed problem-based learning module did not meet all the effective criteria set. Because, there are still indicators of effectiveness that have not been fulfilled, namely the results of the posttest of mathematical critical thinking skills in the first trial that have not met the criteria for classical completeness achievement. However, the effectiveness indicator that was fulfilled in the first trial was that students responded positively to the components of the learning module developed and the classical learning completeness that had not been achieved.

The results of the first trial are used as a reference for improving the developed learning module based on the realistic mathematics approach assisted by the autograph. After a review and revision of the developed learning module has been carried out, the results of the improvements / revisions made to the results of trial I are called draft III and will be retried in trial II.

The description of the results of students' mathematical creative thinking abilities in the second trial is shown in Table 2 . below.

Table 2. Descriptions of Students' Mathematical Creative Thinking Ability Results in Trial II

\begin{tabular}{|l|c|c|}
\hline \multicolumn{1}{|c|}{ Information } & Pretest & Posttest \\
\hline $\begin{array}{l}\text { The highest } \\
\text { score }\end{array}$ & 85,41 & 95,83 \\
\hline Lowest Value & 43,75 & 60,41 \\
\hline Average & 64,64 & 81,51 \\
\hline
\end{tabular}

The percentage of classical completeness criteria for students' mathematical creative thinking abilities in the second trial is presented in Figure 2.

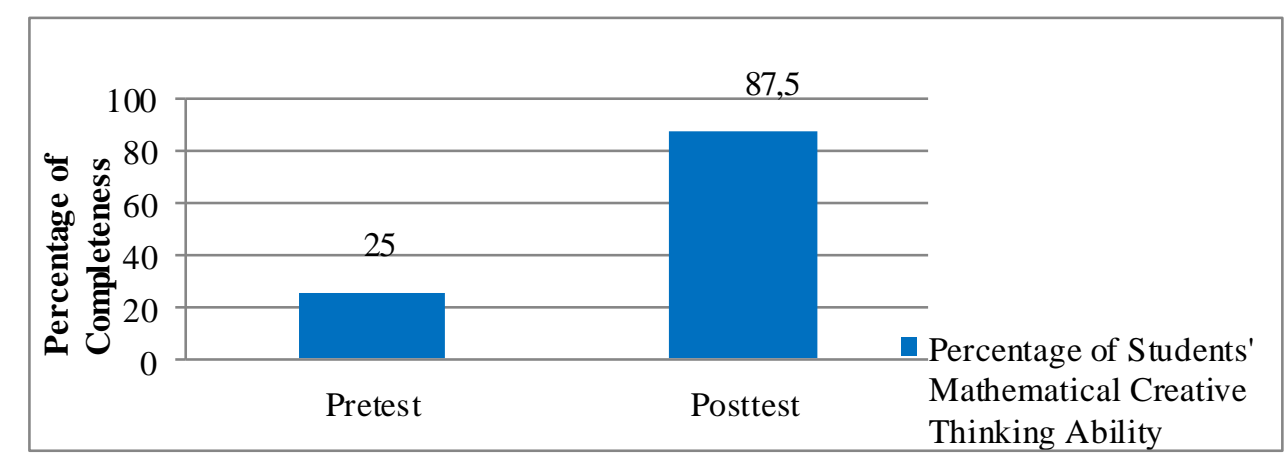

Figure 2. Percentage of Classical Completeness of Students' Mathematical Creative Thinking Ability in Trial II

Based on the data in Table 1 and Figure 2, it can be seen that the classical completeness of the results of students' mathematical creative thinking skills in the pretest trial II was $25 \%$ and the posttest trial II was $87.5 \%$. In accordance with the completeness criteria of classical student learning outcomes, namely at least $85 \%$ of students who take the mathematical creative thinking ability test are able to achieve a score of $\geq 75$. Thus, the posttest results of students' mathematical creative thinking abilities have met completeness 
classically because they obtained a percentage of completeness of $87.5 \%$. So it can be concluded that in Trial II, the application of a learning module based on a realistic mathematics approach assisted by an autograph developed has met the criteria for classical completeness.

The average percentage of student activity in listening to / paying attention to the teacher / friend's explanation at each meeting that was held had met the effectiveness limit. The percentage of student activity at each meeting was $23.1 \%, 25.4 \%, 25.4 \%$, and $22.82 \%$. This indicates that students in starting learning have listened to / paid attention to the teacher's explanation because the learning they are doing has never been done before and they are more active in learning.

Overall, if the average percentage of student activity time is referred to the criteria for ideal percentage of student activity time set in chapter III, it can be concluded that the percentage of student activity time has met the criteria for achieving the percentage of ideal time set.

Based on the results of the student response questionnaire analysis, it can be seen that the average results of the percentage of students' positive responses to each aspect of student responses are as follows: (1) students who expressed pleasure in the learning module components were $90.62 \%$; (2) students stated that the components of the learning module and learning activities were still new as much as $91.25 \%$; (3) students who expressed interest in learning mathematics in other materials such as learning conducted were 93.75\%; (4) students who stated that the language in the module, LAS and tests was clear was $90.62 \%$; (5) students who expressed interest in the performance of the module and LAS were 93.18\%; and (6) students who stated that learning based on a realistic mathematical approach assisted by Autograph was interesting, made fun, useful and helpful, and motivated in learning mathematics as much as $89.37 \%$. Thus it can be said that all aspects received a positive response from students with an overall average score of $90.87 \%$. And if it is viewed from the student's response to learning, the learning module with this realistic mathematics education model can be said to be effective. This is because more than $80 \%$ of students responded positively to the components of the learning module being developed.

Thus, it is known that the results of trial II are better than trial I. This is because the learning module based on the realistic mathematics approach assisted by the Autograph used in the second trial is a learning module based on the realistic mathematical approach with the help of the revised Autograph results of the first trial. then based on the results of trial II it can be concluded that the learning module based on a realistic mathematics approach assisted by Autograph has met the quality of a practical and effective learning module.

After the learning module developed can be said to be of good quality including valid, practical and effective, it will be seen that the increase in students' mathematical creative thinking skills using the developed learning module. The data obtained from the pretest and posttest results of the mathematical creative thinking ability of trial I and trial II were analyzed to determine the increase in students' mathematical creative thinking abilities. The description of the increase in students' mathematical creative thinking skills by using a learning module based on a realistic mathematical approach assisted by Autograph in trial I and trial II is described as follows.

The improvement of students 'mathematical creative thinking skills in the first trial will be seen through the N-Gain of the pre-test and post-test results of students' mathematical creative thinking abilities in the first trial. The summary of the $\mathrm{N}$-Gain results based on the improvement categories that have been defined in Table 3 below. 
Table 3. Summary of N-Gain Results of Students' Mathematical Creative Thinking Ability Trial I

\begin{tabular}{|c|c|c|c|}
\hline Range & Category Improvement & The number of students & Percentage \\
\hline $\mathrm{N} \geq 0,7$ & High & 0 & $0 \%$ \\
\hline $0,3 \leq \mathrm{N}<0,7$ & Medium & 28 & $87,5 \%$ \\
\hline $\mathrm{N}<0,3$ & Low & 4 & $12,5 \%$ \\
\hline
\end{tabular}

Based on Table 3 above, it can be seen that no students got N-Gain scores in the range> 0.7. There are 28 students who have increased their mathematical creative thinking skills in the "moderate" category or get an $\mathrm{N}$-Gain score of $0.3<\mathrm{g} \leq 0.7$, and 4 people who get an $\mathrm{N}$-Gain score $\mathrm{g} \leq 0.3$ with the category " Low". The average gain in the first trial was 0.40 , which is in the medium category. So, it can be concluded that there is an increase in students' mathematical creative thinking skills after implementing learning using a realistic mathematics approach based learning module assisted by Autograph in Trial I.

The improvement of students 'mathematical creative thinking skills in the second trial will be seen through the N-Gain of the pre-test and post-test results of students' mathematical creative thinking abilities in the second trial. The increase was seen by calculating the $\mathrm{N}$-Gain value based on the results of the pretest and posttest in trial II. A summary of the $\mathrm{N}$-Gain results based on the improvement categories that have been defined in Table 4 below.

Table 4. Summary of N-Gain Results on the Mathematical Critical Thinking Ability Test in Trial II

\begin{tabular}{|c|c|c|c|}
\hline Range & $\begin{array}{c}\text { Category } \\
\text { Improvement }\end{array}$ & $\begin{array}{c}\text { The number of } \\
\text { students }\end{array}$ & Percentage \\
\hline $\mathrm{N} \geq 0,7$ & High & 3 & $9,37 \%$ \\
\hline $0,3 \leq \mathrm{N}<0,7$ & Medium & 28 & $87,5 \%$ \\
\hline $\mathrm{N}<0,3$ & Low & 1 & $3,12 \%$ \\
\hline
\end{tabular}

Based on Table 4 above, it can be seen that 3 students got $\mathrm{N}$-Gain scores in the range> 0.7 or experienced an increase in students' mathematical creative thinking skills in the "High" category. For students who experienced an increase in mathematical creative thinking skills of students with the "moderate" category or got an $\mathrm{N}$-Gain score of $0.3<\mathrm{g} \leq$ 0.7 , there were 28 people and 1 student who got an $\mathrm{N}$-Gain score $\mathrm{g} \leq 0.3$ with the category "Low". The average gain in the second trial was 0.49 , which is in the medium category. So, it can be concluded that there is an increase in students' mathematical creative thinking skills after implementing learning using a realistic mathematics approach based learning module assisted by autograph in trial II.

Based on Tables 3 and 4, when viewed based on the N-Gain calculation to see an increase in students' mathematical creative thinking skills in the first trial and second trial, it has increased from 0.36 to 0.50 , meaning that it is in the "medium" category. This shows that students' mathematical creative thinking skills using a learning module that was developed based on a realistic mathematical approach assisted by Autograph have increased from trial I to trial II. Thus the use of a learning module based on a realistic mathematics approach assisted by autographs developed can improve students' mathematical creative thinking skills in the second trial.

The results of the assessment of the practicality of the learning module in terms of teachers and students stated that the learning module developed was easy to use. Then, the 
criteria for practicality in terms of the implementation of the learning module in this study have also met the practical criteria. In the first trial and II test, the implementation of the learning module has met the specified criteria, namely it has reached the good category. This is supported by the results of research by Supentanginingsih and Annurwanda (2019) which have developed a Problem-Based Mathematics Module in the Material of Two Variable Linear Equation Systems which is valid, practical and effective for grade VII junior high school students.

Based on the description above, it can be concluded that the learning module developed based on a realistic mathematical approach with the help of Autograph has fulfilled the practicality as expected. Thus the learning module based on a realistic mathematics approach assisted by autographs developed is easy and can be implemented by teachers and students.

Based on the results of trial I and trial II, the developed learning module based on realistic mathematics approach assisted by autograph has fulfilled the effective category in terms of: (1) classical student learning completeness; (2) the level of active student activity during the learning process; and (3) student responses. In the following, a discussion for each indicator will be presented in measuring and observing the effectiveness of a realistic mathematics approach based learning module with autograph assistance.

The results of the posttest analysis stated earlier that in the first trial the percentage of classical completeness of the mathematical creative thinking ability was $71.87 \%$ while in the second trial the percentage of completeness classified as the mathematical creative thinking ability was $87.5 \%$. If it is seen from the results of students 'classical completeness of learning, the students' mathematical creative thinking abilities, the mastery obtained from the results of the first trial did not meet the classical completeness criteria, while in the second trial it had met the classical completeness criteria.

The results of the above research indicate that students' mastery of classical learning with the developed learning modules meets the effectiveness criteria. Maulydia, Surya and Syahputra. (2017) namely "we can conclude that a teaching material that has been developed through RME has been effective to use". They stated that the learning module developed through PMR could be effective to use. Both of these studies show that module development with PMR can obtain valid and effective modules to use.

This is reinforced by the results of Ariskasari and Pratiwi (2019) who have developed a Problem Solving-Based Mathematical Module on Vector Material for high school students and received a positive response from students. Then by Fitriana, Mohandaz and Risnawati, (2019) developed a Mathematics Module Based on the 5E Learning Cycle to Facilitate Junior High School Students' Mathematical Problem Solving Ability. The results showed that the module developed was valid, practical and effective. Furthermore, Kamid and Ramalisa's research (2019) conducted the Development of a Jambi Culture-Based Middle School Mathematics Learning Module for Autistic Students. The result of the research is that the developed module has a positive response from the environment, especially the research subjects.

The results of research and supporting research, it can be concluded that the components of a learning module based on a realistic mathematics approach assisted by autographs developed have contributed positively to student responses in learning.

The increase in mathematical creative thinking skills above is influenced by the characteristics of learning based on a realistic mathematics approach assisted by autographs combined with the developed learning modules. Among them, the learning module developed contains authentic problems related to the daily life of students.

This is reinforced by the results of research by Zakaria (2017) which concluded that 
"use of Realistic Mathematics Education Approach can be enhanced mathematics achievement of students". This means that using PMR can improve students' mathematics achievement. From the results of this previous research, it can be seen that PMR has advantages in terms of improving mathematical abilities such as reasoning skills, spatial understanding of concepts and in this study what will be improved is the ability to think mathematically creatively. Thus, a realistic mathematics approach model learning module with autograph assistance can improve students' mathematical creative thinking skills.

\section{Conclusion}

The Based on the results of data analysis and discussion in this study, the following conclusions are stated:

1. The practicality of the learning module developed using the Realistic Mathematical Approach assisted by Autograph software is concluded based on (1) the students stated that the device being developed was easy to use; and (2) the teacher stated that the tools developed were easy to use

2. The effectiveness of the learning module developed using the Realistic Mathematical Approach assisted by Autograph software, concluded based on: (i) the students' critical thinking ability obtained classical completeness with a percentage of $87.5 \%$, (ii) the level of student activity met the ideal time tolerance criteria set, (iii) students' responses to the components of learning tools and learning activities are positive.

3. Increasing students' creative thinking skills using learning tools developed through the Realistic Mathematical Approach assisted by Autograph software on the subject of straight line equations is from the average creative thinking ability test in test I of 77.9, increasing in test II to 81.64

4. Student active activities during the learning process in learning with the application of the Realistic Mathematical Approach assisted by Autograph software are already in the limiting criteria for the effectiveness of learning.

\section{References}

Adliani, S., Asmin, and Hasratuddin. (2020). The Influence of Realistic Mathematical Approach to Understanding Concept and the Mathematical Connection Ability of Islamic Private Vocational School Students Hikmatul Fadhillah Medan Class VII. Budapest International Research and Critics in Linguistics and Education (BirLE) Journal Vol 3 (1): 487-499.

Akbar, S. (2013). Instrumen Perangkat Pembelajaran. Bandung: PT. Remaja Rosdakarya.

Ariskasari, D., dan Pratiwi, D.D. (2019), Pengembangan Modul Matematika Berbasis Problem solving pada Materi Vektor, Desimal: Jurnal Matematika, 2 (3), p.249-258.

Dickinson, P \& Hough, S. (2012). Using Realistic Mathematics Education in UK Classrooms. Online.

Fitri, S., \& Zahari, C.L. (2019). The implementation of blended learning to improve understanding of mathematics. The Sixth Seminar Nasional Pendidikan Matematika Universitas Ahmad Dahlan 2018: IOP Conf. Series: Journal of Physics: Conf. Series 1188 (2019) 012109, 2018, doi:10.1088/1742-6596/1188/1/012109.

Fitri, S., Syahputra, E., \& Syahputra, H. (2019). Blended Learning Rotation Model of Cognitive Conflict Strategy to Improve Mathematical Resilience in High School Students. International Journal of Scientific \& Technology Research, 1 (1). 
Fitriana, N, dkk. (2019). Pengembangan Modul Matematika Berbasis Learning Cycle 5E untuk Memfasilitasi Kemampuan Pemecahan Masalah Matematis Siswa Sekolah Menengah Pertama (SMP), Journal for Research in Mathematics Learning, 2 (1), p. 21-31.

Irhamna, Amry, Z., and Syahputra, H. (2020). Contribution of Mathematical Anxiety, Learning Motivation and Self-Confidence to Student's Mathematical Problem Solving. Budapest International Research and Critics in Linguistics and Education (BirLE) Journal Vol 3 (4): 1759-1772.

Kamid dan Ramalisa, Y. (2019). Pengembangan Modul Pembelajaran Matematika SMP Berbasis Budaya Jambi Untuk Siswa Autis. Eduatica, 9 (1), p.75-84.

Mahmudi, Ali. (2009). Komunikasi dalam Pembelajaran Matematika. jurnal MIPMIPA UNHALU. 8 (1).

Martin.(2009). Convergent and Divergent Thinking. Tersedia di : http//www.eruptingmind.com. (diakses 5 Maret 2018)

Maulydia, S. S., Surya, S., dan Syahputra, E. (2017). The Development Of Mathematic Teaching Material Through Realistic Mathematics Education To Increase Mathematical Problem Solving Of Junior High School Students. International Journal Of Advance Research And Innovative Ideas In Education, 3 (2), p. 29652971.

Murdani. (2013). Pengembangan Perangkat pembelajaran Matematika Dengan Pendekatan Realistik Untuk Meningkatkan Penalaran Geometri Spasial Siswa Di SMP Negeri Arun Lhoksumawe. Jurnal Peluang Program Pascasarjana Unsyiah Banda Aceh. 1 (2).

Rambe, N., syahputra, E., Elvis, E. (2020). The Effect of the Jigsaw Cooperative Learning Model and the Student's Initial Mathematical Abilities and Its Effect on the Mathematical Representation Ability and Learning Motivation of Students in the PAB 10 Sampali Private Elementary School. Budapest International Research and Critics in Linguistics and Education (BirLE) Journal Vol 3 (3): 1591-1599.

Safitri, A., Surya, E., Syahputra, E., dan Simbolon, M. (2017). Impact of Indonesian Realistic Mathematics Approach to Students Mathematic Disposition on Chapter Two Composition Function and Invers Fungtion in Grade XI IA-1 SMA Negeri 4 Padangsidimpuan. International Journal of Novel Research in Education and Learning. 4 (2), p. 93-100.

Suprihatiningsih, S. dan Annurwanda , P. (2019). Pengembangan Modul Matematika Berbasis Masalah Pada Materi Sistem Persamaan Linear Dua Variabel. Jurnal Karya Pendidikan Matematika, 6 (1), p, 57-63.

Thiagarajan, Semmel, M. (1974). Instructional Development for Training Teachers of Exceptional Children. A Sourse Book. Bloomington: Central for Innovation on Teaching The Handicapped.

Tuckman. W. Bruce. (1978). Conducting Educational Research. Second Edition, New York : Hartcourt- Brace Jovanovich Inc.

Wena, M. (2008). Strategi Pembelajaran Inovatif Kontemporer Suatu Tinjauan Konseptual Operasional. Jakarta: Bumi Aksara

Wijaya, A. (2012). Pendidikan Matematika Realistik. Yogyakarta: Graha Ilmu.

Zakaria, E dan Syamaun, M. (2017). The Effect of Realistic Mathematics Education Approach on Students' Achievement and Attitudes Towards Mathematics. Mathematics Education Trends and Research, 17(1), p. 32-40. 